\title{
Plant mediated synthesis of silver nanoparticles and study of its bactericidal and anticancer activity against Hela cell line
}

\author{
Shahnaz Majeed \\ Faculty of Pharmacy and Health sciences \\ Universiti Kuala Lumpur Royal College of Medicine Ipoh Perak Malaysia \\ Email: shahnazmajeed5@gmail.com
}

Nanobiotechnology is the emerging area which controls the materials at nano level showed tremendous impact in the field of health sciences. Now a days there is concern about the development of bacterial resistance to various antibiotics is big menace for human life and also various cancers is hard to control when it is malignant. So my present investigation is focused on the synthesis of silver nanoparticles from the plant ie stem aqueous extract of Nepenthes Spp. When the silver nitrate was challenged to the extract of plant, Color of the extract changes in to brown indicates the formation of nanoparticles. These nanoparticles were characterized by UV- Vis spectrophotometry which the qualitative analysis showed the absorbance peak at $430 \mathrm{~nm}$ which is specific for silver nanoparticles. These nanoparticles were further evaluated by using various microscopic techniques like Fourier Transform Infra-red (FTIR) which is used to determine the various proteins, functional groups responsible for stabilization of nanoparticles which showed amines and amides are responsible for the reduction of silver into silver ions and also showed these proteins plays important role for the stabilization of nanoparticles. Transmission Electron Microscopy (TEM) were used to determine the particle size, particle shape and dispersity which showed particles are homogenously dispersed, spherical and are well within the range of 25- $30 \mathrm{~nm}$ in size, stable and homogeneously dispersed. Further these nanoparticles were evaluated for its antibacterial activity by using disc diffusion method, against Staphylococcus aureus, Escherichia coli, Bacillus cereus, Salmonella typhi, and Vibrio cholera and also to determine the synergistic effect with standard antibiotics already present in the market by using different concentration viz $10 \mu \mathrm{g}, 20 \mu \mathrm{g}, 30 \mu \mathrm{g}$ and $40 \mu \mathrm{g}$, These nanoparticles showed good antibacterial activity against these clinically isolated bacterial pathogens and when compare with different antibiotics like Moxifloxacin, Streptomycin and Vancomycin they enhance their bactericidal property after overnight incubation at $37{ }^{\circ} \mathrm{C}$. These nanoparticles were further evaluated for tis anti-cancer activity against Hela cells which showed good activity by using MTT assay by using different concentration. These nanoparticles showed good anticancer activity against Hela cell line.

Biological method approach used for the synthesis of silver nanoparticles is safe, less costly, free from toxic chemical and environmentally friendly. TEM analysis showed that the particles are well within the range of nano size. These silver nanoparticles can be used as strong anticancer and antibacterial material but needs for further evaluation of its toxicity on normal cells before recommended as a strong antibacterial and anticancer agent (Figure 1).
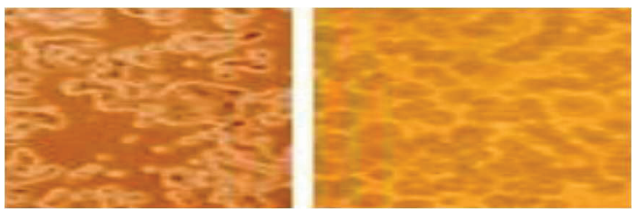

Figure 1: Cytotoxic activity of silver nanoparticles

\section{References}

1. Rai M, Yadav A, Gade As.Biotechnol Adv 27 (2009) 76-83.

2. Marcato PD, Duran N. J Nanosci Nanotechnol. 8(2008)2216-2229.

3. Durán N, Marcato P.D, Conti R.D, Alves O.L, Costa F.T.M, Brocchi M.Potential... J Braz Chem Soc.21 (2010) 949-959.

4. Buzea C, Pacheco II, Robbie K... Biointerphases. 2 (2007)7-71.

5. Kim J S Nanomedicine.3 (2007): 95-101.

6. Siva Kumar V, Nagaraja BM, Shashikala V, Padmasri AH, Madhavendra SS, Raju BD, et al.. J Mol Catal A Chem. 223 (2004)313-9.

7. Sondi I, Salopek-Sondi B. J Colloid Interf Sci. 275 (2004)177-82. 